\title{
The U.S.-Canada Arctic Policy Forum: Impressions from the American Co-Chair
}

\author{
ROBERT L. FRIEDHEIM ${ }^{1}$
}

(Received 25 February 1986; accepted in revised form 21 May 1986)

\begin{abstract}
A U.S.-Canada Arctic Policy Forum, funded by the William H. Donner Foundation, Inc., New York, met to consider the need for U.S.-Canadian cooperation in the Arctic and some of the barriers thereto. The U.S. co-chair assessed the causes of conflict between the two countries, the need for cooperation and some of the sources of each side's conduct and indicated how the delegates - speaking in their capacities as private citizens - worked their way through the issues to the forum's conclusion. Sovereignty questions dominated the conflict issues. But each side had four types of similar internal problems in making arctic policy: 1) native vs. nonnative interests; 2) regional vs. central interests; 3) public vs. private interests; and 4) oil development vs. subsistence and commercial fishing and hunting interests. The forum concluded with suggestions that future meetings use the Canadian Federal Assessment Panel's (or Tener) report as a source of examining possible U.S.-Canadian cooperative measures in the Beaufort Sea region and the Canada-Denmark Agreement as a possible "model" for U.S.-Canadian environmental cooperation in the Arctic.
\end{abstract}

Key words: sovereignty, Northwest Passage, indigenous rights, oil and gas, security, Tener Report, arctic industrialization, scientific cooperation, Beaufort Sea, marine resources

RÉSUMÉ. Un Forum sur la politique arctique canado-américaine, financé par la William H. Donner Foundation, Inc., de New York, fut tenu afin d'envisager la nécessité de la coopération du Canada et des États-Unis dans l'Arctique âinsi que les obstacles attenants. Le co-président américain évalua les causes de conflits entre les deux pays, la nécessité de la coopération, et certaines des sources régissant la conduite des deux parties, et signala la façon dont les délégués traitèrent des questions à travers le Forum, prononçant leurs opinions à titre de simples citoyens. Les questions de souveraineté dominèrent les matières de conflit. Chaque partie manifesta cependant quatre genres de problèmes internes semblables dans la formation de politiques arctiques: 1) intếrêts autochtones contre intêrêts non autochtones; 2) intérêts régionaux contre intérêts centraux; 3) intérêts publics contre intérêts privés; 4) intérêts de l'industrie pétrolifère contre intérêts de chasse et de pêche commerciales et de subsistance. On suggéra en conclusion du forum que les prochaines réunions utilisent le Rapport Tener ou du Bureau fédéral d'examen des évaluations environnementales comme source de mesures de coopération possibles entre le Canada et les États-Unis dans la région de la mer de Beaufort et aussi que l'entente entre le Canada et le Danemark serve de modèle possible pour la coopération environnementale du Canada et des États-Unis dans l'Arctique.

Mots clés: souveraineté, passage du Nord-Ouest, droits autochtones, pétrole et gaz, sécurité, Rapport Tener, industri alisation de l'Arctique, coopération scientifique, mer de Beaufort, ressources marines

Traduit pour le journal par Maurice Guibord.

\section{NEED FOR U.S. -CANADIAN DIALOGUE}

Technology transforms human affairs - even in the Arctic (Young, 1985-86). As the means of exploring and exploiting arctic nonliving and living resources improve, the range, scope and intensity of human intervention in the Arctic increases, altering the balance of human communities and ecosystems.

The effects, however, go well beyond the physical and sociological transformations of the region. There is significant potential impact upon the economies of the states involved, as well as those with whom they are associated in the world political economy. Most important, the political relationship between the geographically contiguous states suffers when each pursues strategies exclusive to itself or at least different from those of its neighbor.

Because Canada and the United States not infrequently seem to pursue different goals in the Arctic, the region has become something of an irritant in U.S.-Canadian relations. With increasing interest demonstrated on both sides of the border in the extraction of resources from the Arctic, and the growing importance of the Arctic as a strategic military region (Critchley, 1984), the problem threatens to get worse and become a cause of serious dissension. For this reason, arctic policy should concern citizens and governments in both countries.

The governments of Canada and the United States in recent years have taken official actions in the Arctic that more often than not have either baffled or exasperated the other party.
There has been confrontation on a significant list of issues jurisdiction over marine transportation in the so-called Northwest Passage, boundary delimitation in the Beaufort Sea, control measures on transboundary pollution problems, the applicability of multilaterally agreed standards, the future of joint development projects, e.g., the Alaska Natural Gas Transportation System (ANGST), and whether native rights are matters wholly subject to domestic jurisdiction or whether they have a transboundary dimension. The most publicly noted of these problems were the "incidents" that occurred when U.S. flag vessels the S.S. Manhattan in 1969 and the U.S.C.G. Polar Sea in 1985 transited the Northwest Passage without requesting permission from the Canadian government.

Unfortunately, government-to-government negotiations tend to be a process of positional maneuvering - that is, Government $\mathrm{A}$ examines its needs and interests by its own unique internal decision process and chooses a policy or position. This position or policy is espoused in negotiation with Government B. In turn, officials in Government B go through a similar process. Each side believes its case is factually correct and corresponds to its interests. Often the position is sold to its internal interest groups as having been created to take care of their needs. As a result, it is often difficult to shift or alter the position or policy if new data are presented. It is very difficult to see if other positions or policies would serve the interest of the client groups as well or almost as well. Finally, too often positions chosen by this process attempt to maximize the

\footnotetext{
${ }^{1}$ University of Southern California, Institute for Marine and Coastal Studies, Sea Grant Institutional Program, University Park, Los Angeles, California 90089-0341, U.S.A.

(C) The Arctic Institute of North America
} 
interest of the proposing state and usually are at best neutral about the interests of the other party or, if relations are bad, perhaps even hostile to those interests. Positional bargaining makes it difficult to discover shared, overlapping or joint interests, much less to help in "getting to yes" (Fisher and Ury, 1981).

Because positional bargaining seems inherent in official negotiations, another form or process is useful, particularly in those situations with a history of conflictual interactions within a larger context of cooperation. What is needed is a situation where shared, overlapping or joint interests might be discovered, where positions are accepted as facts but where the emphasis is on elucidation of needs and interests and where representatives of the interested groups can explore new information or interpretations without compromising their position. In short, what is needed is a private forum sponsored by a party or parties well regarded by all major interested groups and governments.

\section{THE U.S.-CANADA ARCTIC POLICY FORUM}

The purpose of the U.S.-Canada Arctic Policy Forum was to provide a private setting to air some public problems between the two countries. The hope was that such dialogue might identify new ideas or approaches that would assist in reducing conflict and promote cooperation. Participants chosen were knowledgeable persons in the United States and Canada from both public and private sectors, from interest groups with a stake in the future of the Arctic and from academia. Since most participants, especially those in the public sector, had positions they were obliged to defend if they attended in their official capacities, all participants were invited to attend as private citizens. To promote forthrightness, the organizers promised participants anonymity; thus, no individual is quoted in this assessment of the work of the forum. But the quality of the dialogue is directly proportional to the intellectual quality and arctic experience of the participants. As the names and positions of those listed in the Appendix indicate, many years of wisdom and experience were available.

The idea of a forum for the purpose of seeking new ideas for resolving U.S. -Canadian arctic problems originated with James Zumberge, glaciologist, president, University of Southern California, and subsequent to the meeting of the forum chairman, U.S. Arctic Research Commission. The William H. Donner Foundation, Incorporated, of New York, financially supported the forum after Robert Friedheim and Michael Fry of USC and Harriet Critchley, University of Calgary, agreed to organize it as a binational effort.

What follows is not a neutral report. The Proceedings (1984) accomplishes that task. What I have tried to do - as fairmindedly as possible - is to report my impressions of what was said and, even less neutral, what was meant by many speakers. In sum, I have made judgments. Judgments display biases. I must admit to being biased not only by my citizenship, but also by my status as an academic, as a former researcher for the U.S. government on law of the sea matters and finally, as my Alaskan friends might point out, by my nonresidence in the Arctic.

\section{CONFLICT PATTERNS ON ARCTIC PROBLEMS}

In the two days of discussions certain themes stood out, with many variations. The main themes were striking and there was a discernible difference in the general approaches of the two national groups. After an initial session to get the discussions going, the binational group broke up into national caucuses. Each caucus report was very different in style and substance.

The Canadian spokesperson reported in detail on the substance of the discussions within the Canadian group:

The Canadian group . . . tried to identify the core interests of Canada in the Arctic. Any further development of these core ideas would require the establishment of priorities and timing.

The group rapidly came to the conclusion that for Canada the Arctic was a conceptual problem. It was a whole that was not easily divided. Canada's interest was an integrated one. First, Canada was concerned with integration of northerners into the Canadian economy and society. Related to this was a second core interest of treating the problems of resources, environment and people as a synthesis whose elements are closely intertwined. It was thought that U.S. interests in the Arctic were not as thoroughly integrated. A third important core interest was the maintenance of traditional lifestyles in the North.

On a fourth area - resources - the Canadian group emphasized the importance of developing arctic resources in the interest of Canadians, especially in the light of the previously mentioned concern for the maintenance of traditional lifestyles. It was assumed by the Canadian group that resources automatically included transportation. But which companies produce which resources, and therefore which transport mode they chose, will be more up to chance and economics than to a public policy decision.

Another aspect of the resource interest is the resource itself, particularly establishing the extent of the resource. Canada needs this information to establish the timing and pace of development.

Canadians view the development of arctic technology as a core interest because it is viewed as an aspect of the development of Canadian high technology. Canadians wish to get away from heavy dependence on natural resource exports. High technology is viewed as a way out of the traditional self-portrait of being hewers of wood and haulers of water. Employment spinoffs from arctic development in the Canadian south as well as north is viewed as a core interest. For resource development as a whole, domestic policy issues have a much higher priority for Canadians than perhaps for Americans. Thus the boundary dispute in the Beaufort Sea is seen as one of the least important issues. Canadian oil and gas people claim they have plenty of lease areas to explore before the question of the disputed area must come up for resolution.

One issue which might come up for transnational discussion is the difference in the regulatory process. Canada and the United States require different data. Moreover, they can put different interpretations on the data. There are a number of important issues to resolve here.

Marine resources per se are best discussed under the heading of environmental and social questions because Canadians see marine resource development in the context of adequate marine environmental protection. Thus, an important question to raise at the forum is what measures do we have in place in Canada and the United States to protect the marine environment? For example, a case can be made for the movement of Canadian high arctic oil to Japan going west rather than east. There should be an interface between social impacts, marine mammals and fish stocks with the native peoples' concerns. However, land claims which are matters of domestic concern for both countries should not be part of the transnational discussions.

Security was mentioned as a core interest. There is an important distinction between the U.S. and Canadian views of security. For the United States, national security usually refers to relations with one country, the USSR. In the Canadian view, 
national security in the Arctic refers to a number of arctic littoral states and otherwise. Moreover, in the Canadian view, there is an environmental component to its national security interests in the Arctic. Canada is concerned that marine pollution problems might become potential threats to the peace and good order of the region. This is consistent with the fact that in Canada, foreign policy basically serves domestic needs. In the United States, because it is a superpower, foreign policy serves U.S. needs in the global environment. [Proceedings, 1984.]

The American group used its time in a very different manner. After extended discussion on the nature of U.S. interests in the Arctic, the group made an attempt to identify the issues on which a purely national set of decisions would probably be ineffective and where perhaps there are some shared interests between the United States and Canada. It was decided by consensus to put the group's conclusions into the following statement:

Canada and the United States should exert joint leadership to the solution of the problems of the Arctic that reflect the mutual interest of both countries. These solutions preferably should be sought in an appropriate cooperative mechanism.

The approach of Article 234 - that the Arctic is a special zone - is acceptable in principle.

In developing arctic resources, we need common approaches to the eastward and westward passage to or from the Beaufort Sea area. With these must come early consideration of issues that can best be dealt with bilaterally or multilaterally.

These might include:

1) bowhead whales

2) the habitat of northern peoples

3) protection of the ecosystem

4) scientific interests/research

[Proceedings, 1984.]

The U.S. spokesperson explained that although the American group had basic national concerns, it preferred to seek common grounds for cooperation on subjects of mutual concern. What the American group hoped the forum would achieve was an agreed statement of principles.

So much for separating positions from interests. The caucus statements are a reminder that positions are developed from the perceptions of the decision makers concerning a given situation. While the position they choose may not be the only way to promote a favorable outcome for the decision maker, if he or she is competent, it is one way of promoting a favorable outcome. Moreover, central to the perception of the situation are not only the facts of the particular case, but the general context in which the case is viewed.

The context in many aspects of U.S.-Canadian relations is that of a superpower with approximately ten times the population sharing the continent with a state with a larger land mass, a separate history, a dependent economy and a "North" that is part of its national myth and consciousness. The less powerful attempting to avoid the embrace of the more powerful is a common behavior pattern in asymmetrical situations in international politics (Dolan and Tomlin, 1984) - even where the embrace is well meant (and that assumption is always closely examined by the less powerful!). On the other hand, the more powerful state will usually have multiple interests and obligations, broader geographic reach, and be less able to isolate the problems of a particular region from its general obligations, even if it is conscious of the importance of not smothering its less powerful friends (a necessity of U.S. foreign policy sometimes thought lacking by some U.S. friends).
Canada's approach to the Arctic is overtly nationalistic. What most Canadians have believed for some time is "that the Arctic above the Canadian land mass up to the North Pole is, quite simply, Canadian . . ." (Kirton, 1984). That has meant that, in several steps over time, the Canadian government has made sovereignty claims to northern waters that the U.S. government has never conceded are subject to any state's sovereignty. That is the core issue in the North between the United States and Canada. It is an emotional issue, indeed a symbolic issue, especially in Canada, though it does strike some emotional responses from the South. While I believe my description of Canadian behavior will pass muster under any definition drawn from the literature on nationalism (Kohn, 1955), it is often assumed that such a description if given by an American has prescriptive overtones. It would be difficult for me to deny that possibility considering the fact that I was trained in the McDougalian tradition that I shall invoke below.

While the U.S. opening statement sounds - and was intended to be - conciliatory, it does not concede the one fundamental goal the Canadians assembled desired from Americans: sovereignty over the water areas in question. Nor did it indicate even a willingness to discuss sovereignty. In effect, the United States group said it thought the U.S. government would be forthcoming about increased Canadian control of activities in the Canadian 200-mile exclusive economic zone, since coastal states are entitled to special treatment in ice-covered areas to prevent "irreversible disturbance of the ecological balance" (UNCLOS Treaty, 1982: Article 234).

The United States position, if less "nationalistic," was no less calculated to foster the U.S. national interest than the Canadian position was to foster theirs. Since as a superpower a hegemon (Keohane, 1984) - the United States is concerned about its worldwide reach by sea and air, it has feared "enclosure" moves that would threaten its strategic mobility, especially through straits. Since the Truman Proclamation in 1945 claimed for the United States rights over the "continental shelf," the U.S. government has been ambivalent about maritime claims. On the one hand, the United States has encouraged "enclosure" for resource purposes; on the other hand, it has resisted "sovereign" forms of enclosure because of the potential impact upon the mobility of its civilians and military ships and aircraft. It has fought hard in many fora to prevent the establishment of an adverse precedent. Canadian offers, frequently hinted at during the long history of this controversy, to grant the U.S. special status in its arctic waters in return for an admission by the U.S. of Canadian sovereignty have, thus far, fallen upon deaf ears. While the United States has growing specific interests in the Arctic for resource exploitation and regional military strategic considerations, the cornerstone of its approach is its view of its needs as a superpower. It refuses to convert what it claims to be a right to a privilege. Moreover, some State Department lawyers take moral comfort in claiming that the United States is defending what two of the major American theoreticians of ocean law characterized as a law of "inclusion," while viewing what Canada wishes to do in the Arctic as an aspect of a law of "exclusion" (McDougal and Burke, 1962:63). In other words, in its own view, the United States position represents the world's general interest.

The brevity of the U.S. statement masked some important factors concerning the U.S. stance in the Arctic that inevitably affect the way Americans approach the problems of U.S. -Canadian relations in the Arctic. First, there is a dynamic tension 
within the U.S. political system concerning arctic policy because of the relative equality of strength of the political inputs. It is obvious that in the past the general great power role of the U.S. and the influence of the Department of Defense have been important factors in the positions the U.S. adopted in the Arctic. They are still important today. Indeed, with the limited but alarming information available about under-ice operations of Soviet submarines - especially those armed with nuclear missiles - and the difficulties of conducting antisubmarine warfare in ice-covered areas (Le Marchand, 1985), it is very likely that the Department of Defense will continue to have a major voice in U.S. arctic policy. What changes will occur if the Department of Defense perceives an increased threat to U.S. security that might be initiated from the Arctic was difficult to discuss at the forum given the limited information available and therefore was masked over.

What makes the situation dynamic is that the Arctic has become increasingly important to the United States for resource purposes and that the political voice of its spokespersons has become both louder and more often heard. Alaska is no longer the least populated of the fifty United States. It now has over 521000 people. To be sure, only a relatively small percentage live above the Arctic Circle, but a substantial percentage depend for their livelihood on resource exploitation above the Arctic Circle. Forty to fifty percent of known U.S. domestic reserves of oil and gas are in the Arctic (National Petroleum Council, 1981). Enormous investments in the arctic oil pipeline and marine terminal facilities have been made. Even if the North is not part of the U.S. national myth, the United States is increasingly conscious of its arctic assets and problems.

Alaska has a significant political voice in the U.S. political system. It seems to me that some of our Canadian colleagues at the forum misunderstood the importance of Alaska in U.S. politics because Alaskans at the forum complained so loud and long about U.S. government neglect or even mischief. Nevertheless, Alaska has two senators with seniority and a congressman of the president's party in Washington. If Alaska does not get all it wants, or its citizens still feel they are geographically separated outsiders, they are heard.

The common complaint is fragmentation in the decision process on arctic issues in the United States. While true, it is also true of a number of other areas of policy concern in the United States, for example in ocean policy generally (Hoole $e t$ al., 1981). Fragmentation may still exist, but numerous efforts to understand the problems and propose solutions have been and are being made by in-house studies within the federal government (Interagency Arctic Research Policy Committee, 1985), by state agencies (Scientific Advisory Commission, 1985), the National Academies of Science and Engineering (Polar Research Board, 1985), Congress (Office of Technology Assessment, 1985) and a presidentially appointed Arctic Research Commission (U.S. Arctic Research Commission, 1986).

Finally, Alaska and Alaskans are increasingly being integrated into the life of the lower 48 states. It may be occurring willy nilly, and some complain that the policies chosen are not appropriate and that Alaskans - especially the indigenous people - will pay dearly for the changes wrought (Berger, 1986), but the Alaska of today is significantly different from the Alaska prior to the shipment of the first oil south from Prudhoe Bay. The U.S. is further along in arctic "industrialization" than Canada, and it is further along in concluding the status of the indigenous people by integrating them into a capitalist econ- omy. The key question is not what basic steps the U.S. should take, but how effectively those steps already taken will work. If the Alaska Native Claims Settlement Act is not amended, we may know after 1991 when native lands deeds become eligible for potential resale (Yarrow, 1985).

The participants at the Arctic Forum agreed to disagree about sovereignty issues and get on with forum business. This was good enough for forum purposes. Agreeing to disagree also seemed to be good enough to keep arctic problems from becoming a major source of dissension in U.S.-Canadian relations until the Canadian government in response to the Polar Sea "incident" invoked a straight baseline concept for defining Canada's Arctic Ocean border. The effect of enabling legislation was to create, as of 1 January 1986, a baseline for Canada's territorial sea by drawing a straight line connecting the headlands of the outmost islands of the Canadian archipelago. Everything within would become the internal waters of Canada, possibly subjecting all who would enter to Canada's sovereign control (Territorial Sea Geographic Coordinates: Area 7 Order, P.C. 1985-2739). At this stage, agreeing to disagree will no longer work.

Another striking aspect of the forum was the similarity of general structural problems both sides faced in the formulation of domestic arctic policies. Both countries are subject to "crosscutting cleavages" (Axelrod, 1969), that is, the stakeholders are pulling in different directions, making it difficult to have a single coherent thrust to policy. The accents were slightly different, but the complaints on both sides of the border on northern policy sounded remarkably similar. Four patterns were discernible: 1) native vs. non-native interests; 2) regional vs. central interests; 3) public vs. private interests; and 4) oil development vs. subsistence and commercial fishing and hunting.

Who are the appropriate beneficiaries of "sound" policies in the Arctic - all who live there, or the native peoples? Who should make the decisions that affect their lives? Both Canadian and American speakers felt that the native peoples should be involved as much as possible in their own governance. Some even suggested that the indigenous people should be involved in the analysis of scientific data. Indeed, the question was raised as to whether the interests of the native peoples were properly represented at the forum, since, although native participants were invited, none was able to attend (the science advisor of the North Slope Borough attended in the place of the invited mayor).

As we have seen, the Alaskan participants were vocal about where decisions relating to the future of the Arctic should be made - in the North or in the national capital. Canadian representatives were more polite about Ottawa, but the message was similar: the center exercised too heavy a hand on regional governance.

Public regulatory needs and private market uncertainties also affected both sides. What was needed to control the "industrialization" of the North? Many opinions were expressed but there were no "national" positions espoused by either side concerning the problems of implementation. Some of these uncertainties arose from the fact that many of the key decisions relating to the development of the Arctic will be made by the private sector. For example, there was considerable discussion as to whether Canadian arctic oil companies were interested in exploring the possibility of shipping crude to a Far Eastern market via ships moving through the Bering Strait. This was characterized as a "prospect." Much depends upon the size of the finds. Smaller 
and more remote finds may require a marine method to get the product to market. But that market also may be eastern Canada, Europe or the eastern United States. If a major find is made in the Mackenzie Delta, a pipeline might make more sense. But until private decisions are made, it is difficult to predict what regulatory needs there will be, although there were strong preferences expressed, especially by the North Slope Borough representative, for having regulations in place before marine transportation of arctic oil occurs.

The question of development was an emotional issue on both sides. The boom-and-bust impacts of oil exploitation on the native peoples were contrasted with preservation of their subsistence lifestyle. The cash economy inevitably changes living patterns, health and values. There was also considerable discussion as to whether questions relating to the rights of native peoples were a proper subject of a transnational forum, since these, in a legal sense, are matters wholly within domestic jurisdiction. Other speakers pointed out that even if this were so legally, the native peoples themselves have organized on a trilateral basis (Canada-U.S.-Greenland) in the Inuit Circumpolar Conference and that any hope of treating native rights issues entirely on a national basis was doomed from the start.

It seemed to me that, despite significant national differences in emphasis and detail, a number of speakers from both arctic nations were united in their concern that domestically the decision process was fragmented, there were too many stakeholders pulling in too many opposing directions and there was insufficient attention within the nation as a whole to the role the Arctic should play in their national system. In sum, policy was not well centered, was "weak," or at least inadequate for addressing the problems.

\section{U.S.-CANADA COOPERATION ON ARCTIC PROBLEMS}

Although at a transnational forum there is rarely a single time when concerns about maintaining the integrity of one's position become transformed into a concern for maximizing one's national benefits through cooperation, the participants at the forum did make that transition. Yet even in discussion of how both could mutually benefit, the language of cooperation was first scrutinized to see what might have been meant.

Canadians asked what the American group meant in its statement by the phrases "joint leadership" and "common approaches." After considerable discussion most participants were content with the explanation that no specific arrangement was intended but rather that in the discussion of arctic problems with transnational aspects the two countries might view the problems in the following roughly established hierarchy.

At the lowest level we could be concerned with information interchange. There are gaps in information needed by both countries that might be filled more effectively by developing new patterns of information exchange.

At the next level, we could be concerned with active cooperation on certain matters. In particular, there was concern expressed about the possibility that we might develop divergent regulatory requirements on exploitation of natural resources, environmental management and marine transportation that would disaccommodate or even harm the other. While many of these matters are within the domestic jurisdiction of one of the parties, their actions may have transnational impacts. Cooperation in this case would require an effort to coordinate our legally separate actions.
Finally, there was discussion of "joint management," which, while not defined precisely, seemed to mean a system of decision that required mutual consent, probably on those problems that have significant transnational impact, and where the two governments may have a de facto veto over the action of the other if its consent is not secured. Both sides were comfortable with the first two levels - information interchange and coordination - but the Canadian group, while willing to listen to discussions of "joint management," wanted it understood that they were not committed to its pursuit.

Several speakers from both countries pointed out that while we extolled the idea of information exchange across our common border, it is already proceeding - and at a rapid rate within industry. A Canadian pointed out that there is a common interest in developing arctic technology. The same challenges face industry in both national "norths." Moreover, multinational enterprises have interests on both sides of the border, and it is a common practice to transfer technology. He thought it ironic that there was probably less information exchange government-to-government than was already taking place within the private sector.

A number of speakers emphasized the need for better links on arctic research, certainly in exchanging information and perhaps in active coordination of projects. Both sides perceived weaknesses in the use of scientific data in domestic governmental decision making. Duplication of effort in a high-cost environment is perennially a matter of concern. Whatever the outcome of the jurisdictional questions, if marine transport systems that function well in the Arctic are to be developed, whoever makes the rules needs data to require or regulate routing, provide an ice forecast, emplace buoys and other navigational aids, develop regulations to prevent, clean up or otherwise mitigate spills and compensate those harmed by pollution and coordinate the actions of coast guards on regulation enforcement and search and rescue. For regulatory purposes generally both governments need extensive sets of baseline data.

A Canadian indicated that the idea of cooperation on science was not a problem, but joint funding, data sharing and the provision of joint scientific services could be a problem - of the most pragmatic sort. Commitments are needed to coordinate data gathering, maintain common data standards and provide a reliable stream of funding. This is difficult enough within a single system, much more difficult when two systems must respond in similar fashion. However, the opportunities are there. He noted that in the Beaufort Sea the currents, and the potential pollution, flow from east to west. What is needed are data from agencies on both sides of the border that are comparable. Another area where cooperation is needed is on ice information, particularly offshore wind effects, needed for navigational safety. LANDSAT images would be essential for this task, but the U.S. facility in Fairbanks that can do real-time analysis is underutilized. On the other hand, Canada has the facilities to do more sophisticated analyses. Joint funding and joint activities on satellite research might have a significant payoff for both countries.

All participants recognized the political and bureaucratic impediments. Cooperation that will lead to useful results requires formal structures to help in the transfer of information. Formal structures - real organizations - need real budgets and real budget allocations. It was difficult for any participant to propose a particular cooperative organization in the light of the financial 
constraints of recent times. Yet precisely because of the reduction of the fortunes of the oil industry in a world market awash with oil, it makes sense not only to reduce the cost of environmental regulation through cooperation in the acquisition of the necessary environmental data, but possibly also for the oil industries and geological surveys to cooperate to reduce prospecting costs. Existing cooperative mechanisms have been limited by subject matter and budget. Approximately every 18 months over the last ten years, a Subcommittee on Science and Technology of the Canadian Advisory Committee on Northern Development has met with its American counterpart. For the most part the subject has been science related. A Canadian reported that the agencies concerned have felt that, at best, the meetings have been useful to give advanced warnings of problems or indicate where some form of joint action is appropriate. At worst, the meetings have been useful as safety valves.

Despite the concern that there are myriad problems of native peoples of the North finding a place in the modern world where they can take advantage of the material benefits of being citizens of an industrial society without giving up their culture, it was recognized that these are problems wholly within the domestic jurisdiction of the states concerned. As the forum progressed there was an increasing recognition that both the United States and Canada face similar problems. As I mentioned, the United States has already implemented some forms of settlement of native claims. These may be changed, but it is unlikely the U.S. will reverse its course completely. Nevertheless, we can learn from each other. Moreover, the Inuit themselves organized in the Circumpolar Conference will force comparisons.

Perhaps it was this awareness that both governments will be subject to pressures from the native peoples of the North that made a number of Canadians and Americans look favorably upon the idea of cooperation in providing health services for the indigenous people. Another factor might have been the distinctive health problems of people in isolated communities and settlements or the costs of providing health services. In any case, the participants thought this was a potential area of need where cooperation might have payoffs.

The most obvious rationale for cooperative efforts at the first two levels of interaction discussed, information exchange and coordination, and perhaps even at the third level of joint efforts, is that some of the problems have transboundary impacts. In short, it is virtually impossible to confine the effects of human use and natural processes to a politically defined geographic area. This is most evident where the area concerned exhibits the characteristics of a natural common. Where water flows regardless of manmade law, it is impossible to insist that pollutants, fish and other positive and negative amenities remain on one side of the border. Even on land, where we are accustomed to thinking of fences as nonpermeable, in the Arctic fences virtually do not exist. Moreover, at the present stage of development no one considers it desirable to try to constrain the migration of the caribou or the wanderings of polar bears. Finally, it seemed to me that there was a general awareness that, if each country chose to maximize only its short-run benefit without regard to the other, it might be possible to suffer a common disaster, a tragedy of the commons (Hardin, 1968).

The regions of the two countries that share a common border feel most immediately the problems that arise from the area being treated as a common. They have powerful incentives to cooperate, as the delegates to the forum recognized. An American noted that there were already functioning scientist-to- scientist relationships between scientists in Alaska and the Northwest Territories. Although they are working well, hope was expressed that the forum could help in cementing these ties in the future.

Cooperation is most needed, as almost all at the forum recognized, in the area of the Beaufort Sea. On the American side of the border it is already "industrialized" and its native people have already felt the impact of a market economy. They have their own form of local self-government, the North Slope Borough, which just prior to the convening of the forum was going through political turmoil with a bitterly contested election. Its people fear that further exploitation of oil and gas and any resultant pollution or the use of tankers to bring product to market may interfere with the migration of the bowhead whale, the taking of which they claim is critical to their cultural identity. Their nervousness on questions of marine transportation will require answers from both American, and if the "prospect" of the movement of Canadian oil to Asian markets becomes a probability or reality, Canadian authorities.

At the time the forum was meeting, hopes were high but there was little information about whether a major oil pool existed in the Canadian Beaufort Sea. The hopes apparently have been justified with a find by Gulf Canada Ltd. at its I-65 well at Amauligak, which has been calculated to have reserves of 700-800 million barrels (Wall Street Journal, 1986). Many of the problems that will be encountered have counterparts in American experience. Moreover, Alaskans are anticipating that if any difficulties are encountered because the currents run from east to west in the Beaufort Sea, they will not remain exclusively Canadian difficulties. Even if Canadian authorities manage through wise policies to avoid all or most of the feared difficulties, all interested parties on both sides of the border want to feel assured as much in advance as possible.

The Canadian group at the forum indicated that a Canadian study group had already done most of the work necessary to be reasonably confident that in the implementation stage the Canadian government can provide such assurances. A federal assessment panel had already reviewed many of the key questions related to development. It looked at both submarine pipeline and ship options for Dome, Esso and Gulf. It assessed tanker designs, safety and navigation questions, management of ship traffic, oil spill responsibility and impact upon people and animals. The report, often called the Tener Report after its chairman, John S. Tener, identified a need for a single authority in the Beaufort Sea to manage oil spill cleanups. It also identified some areas of potential bilateral cooperation. These include the ice regime in the Beaufort Sea, meteorology (the engine driving the weather system), the biology of the Beaufort Sea (fish populations, food chains, etc.), safety of ship passage and modeling of the weather system (so that it will be possible to design better spill cleanup systems). The panel recommended that there be no tanker traffic until all of the problems have been thoroughly researched (Federal Environmental Assessment Panel, 1984).

It was suggested that the Tener Report be used as the basis for a future meeting of the U.S.-Canada Arctic Forum. It would allow a binational group to focus on some of the key problems of the Beaufort Sea region in a structured manner. The suggestion was greeted with enthusiasm because there is no comparable document on the American side. While there have been many scientific studies of the Beaufort Sea - a huge library of environmental assessments was compiled before leasing in U.S. 
federal waters - there was no study that focused on the broad policy questions relating to exploitation and movement of oil and its impact on the people and biota of the region. Nevertheless, the raw materials are available at the Arctic Environmental Information and Data Center of the University of Alaska.

Although there was considerable concurrence between participants, whatever their nationality, on the nature of the substantive problems in the Arctic that both countries must solve, either separately or together, we struggled to find a process of interaction that would satisfy both sides. One suggestion was to look for a "model" regime that has been applied elsewhere in similar circumstances that might provide a useful basis of comparison.

An American suggested that perhaps in the future we could examine the Canada-Denmark Agreement concerning the environmental issues in the waters that separate Greenland and Canada to determine whether there are some useful precedents. The agreement includes provisions for the exchange of scientific information, cooperation on pollution prevention, vessel routing, compensation for damages and cleanup costs, access to each other's vessels and the specification of the geographic area covered. In addition, a dispute settlement procedure was established (Agreement between . . . 1984).

The suggestion was greeted with general enthusiasm. It seemed to me that, in part, the positive response was due to the fact that the suggestion somewhat assuaged an earlier concern as to whether we could look at arctic problems - some of which are generic to the region - in a strictly U.S.-Canadian context, since there are other players in the region. One of the expressed concerns was the possibility of development of regulations on a national level that would be so idiosyncratic as to frustrate a user of arctic waters, such as a ship captain who might have to obey a series of contradictory regulations on a continuous voyage through waters regulated by two or more states. If Canada and Denmark have come to a satisfactory resolution of some of these problems, it would argue for a broader application of some of the required practices.

\section{WHERE DO WE GO FROM HERE?}

I believe most participants left the meeting with the feeling that the several days we spent together were worth their time. We did not resolve any major problem in U.S.-Canadian arctic relations, but then as an informal study group we realized that we were not empowered to do that. We tried to express honest opinions, inform each other of what we thought about the problems and introduce a few new, innovative ideas.

The major value of the meeting was to sketch out an agenda for future informal and, perhaps further in the future, more formal U.S.-Canadian interactions in the Arctic. We discovered that we are both concerned about the future of development in the Arctic, especially in the Beaufort Sea. We believe that a thorough examination of the transnational problems that will arise from the further development of the Beaufort Sea region and the patterns of transnational cooperation needed, at least at the level of information exchange and coordination of our separate policies, if not joint management, is a priority item. We hope to be able to tackle these matters in a future forum. We also believe we can learn to coordinate by example. Thus, another priority item would be a session that will consider whether the Canada-Denmark agreement has worked, and if so, how well it has worked and how generalizable its rules might be to other areas of the Arctic.
We also reinforced our existing awareness of how difficult it is to cope with problems on which states have chosen positions. We were able to work around the jurisdictional questions, but we could not ignore them. Unfortunately neither could our two states. Nevertheless, whatever the outcome of the jurisdictional quarrels, other problems remain that must be solved if the arctic states of the North American continent are to maximize their long-run interests in wise use of the resource rich, sparsely settled and environmentally fragile North. We hope that we have helped in focusing attention on the nature of those interests and on some of the means for maximizing them.

\section{REFERENCES}

AGREEMENT BETWEEN THE GOVERNMENT OF CANADA AND THE GOVERNMENT OF THE KINGDOM OF DENMARK FOR COOPERATION RELATING TO THE MARINE ENVIRONMENT, AUGUST 26, 1983. 1984. In: Intemational Legal Materials 23:269.

AXELROD, R. 1969. Conflict of Interest: A Theory of Divergent Goals with Application to Politics. Chicago: Markham.

BERGER, T.R. 1986. The Report of the Alaska Native Review Commission. New York: Farrar, Straus, Giroux.

CRITCHLEY, H.W. 1984. Polar Deployment of Soviet Submarines. International Journal 39:828-865.

DOLAN, M., and TOMLIN, B.W. 1984. Foreign Policy in Asymmetrical Dyads: Theoretical Reformulation and Empirical Analysis, Canada-U.S. Relations, 1963-1972. International Studies Quarterly 28(3):349-368.

FEDERAL ENVIRONMENTAL ASSESSMENT PANEL. 1984. Beaufort Sea Hydrocarbon Production and Transportation Proposal. Hull, Quebec: Federal Environmental Assessment Review Office.

FISHER, R., and URY, W. 1981. Getting to Yes: Negotiating Agreement without Giving in. Boston: Houghton Mifflin.

HARDIN, G. 1968. The Tragedy of the Commons. Science 162:1243-1248.

HOOLE, W., FRIEDHEIM, R.L., and HENNESSEY, T. 1981. Making Ocean Policy: The Politics of Government Organization and Management. Boulder: Westview.

INTERAGENCY ARCTIC RESEARCH POLICY COMMITTEE. 1985. Federal Arctic Research: Detailed List of Existing Programs. Washington, D.C.: U.S. Government Printing Office. Unpubl. 136 p. Available from National Technical Information Service, U.S. Department of Commerce, Springfield, VA.

KEOHANE, R.O. 1984. After Hegemony: Cooperation and Discord in the World Political Economy. Princeton: Princeton University Press.

KIRTON, J. 1984. Beyond Bilateralism: United States-Canadian Cooperation in the Arctic. In: Westermeyer, W., and Schusterich, K., eds. United States Arctic Interests: the 1980s and 1990s. New York: Springer-Verlag. p. 296.

KOHN, H. 1955. Nationalism: Its Meaning and History. Princeton: Van Nostrand.

LE MARCHAND, T.D. 1985. Under Ice Operations. Naval War College Review 38(3): 19-27

McDOUGAL, M.S., and BURKE, W.T. 1962. The Public Order of the Oceans. New Haven: Yale University Press.

NATIONAL PETROLEUM COUNCIL. 1981. U.S. Arctic Oil and Gas. Washington, D.C.: National Petroleum Council.

OFFICE OF TECHNOLOGY ASSESSMENT. 1985. Oil and Gas Technologies for the Arctic and Deep Water. OTA-0-270. Washington: U.S. Congress, OTA

POLAR RESEARCH BOARD. Commission on Physical Sciences, Mathematics, and Resources. 1985. National Issues and Research Priorities in the Arctic. Washington, D.C.: National Research Council.

PROCEEDINGS: U.S.-CANADA ARCTIC POLICY FORUM. 1984. In: Final Report to the William H. Donner Foundation, Inc., on the U.S. -Canada Arctic Policy Forum. Submitted by Robert L. Friedheim. Unpubl. Available upon request from the author, Sea Grant Program, University of Southern California, Los Angeles, CA, U.S.A. 90089-0341.

SCIENTIFIC ADVISORY COMMISSION, UNIVERSITY OF ALASKA FOUNDATION. 1985. Trustee of Alaska's Future. Fairbanks: University of Alaska. Unpubl. Available from the University of Alaska Foundation, 590 University Avenue, Suite 101, Fairbanks, Alaska 99701.

TERRITORIAL SEA GEOGRAPHIC COORDINATES: AREA 7 ORDER, P.C. 1985.-2739.

UNITED NATIONS CONVENTION ON THE LAW OF THE SEA, 1982. 
1983. Official Text of the United Nations Convention on the Law of the Sea. New York: United Nations.

U.S. ARCTIC RESEARCH COMMISSION. 1986. U.S. on the Arctic Rim. Report of the U.S. Arctic Research Commission to the President and the Congress of the United States of America, for the Period 1 March-30 September 1985. Los Angeles: U.S. Arctic Research Commission.

WALL STREET JOURNAL. 1986. Gulf Canada Test of Beaufort Sea Well Results in 83\% Rise in Find's Capacity. January 28:12.

YARROW, A.L. 1985. Alaska's Natives Try a Taste of Capitalism. New York Times Magazine. 17 March: $36 \mathrm{ff}$.

YOUNG, O.R. 1985-86. The Age of the Arctic. Foreign Policy 61:160-179.

APPENDIX. Attendees, U.S.-Canada Arctic Policy Forum, 20-23 October 1984

\section{CANADA}

Harriet Critchley, Director, Northern Political Studies Programme, University of Calgary, Calgary, Alberta

Kenneth R. Croasdale, Consultant, K.R. Croasdale \& Associates, Calgary, Alberta

Michael Fry, Director, School of International Relations, University of Southern California, Los Angeles, California

Keith Greenaway, Consultant, Northern Policy \& Research, Ottawa, Ontario

John Hucker, Director General, Northern Policy, Department of Indian Affairs \& Northern Developments, Hull, Quebec

Barry Mawinney, Director General, Legal Affairs, Department of External Affairs, Ottawa, Ontario

Donald McRae, Professor of Law, University of British Columbia, Ottawa, Ontario

John Parker, Commissioner, Northwest Territories, Yellowknife, N.W.T.
Donat Pharand, Professor of Law, University of Ottawa, Ottawa, Ontario

Fred Roots, Science Advisor, Department of Environment, Ottawa, Ontario

John Tener, Ottawa, Ontario

David VanderZwaag, Research Associate, Dalhousie Ocean Studies Program, Halifax, Nova Scotia

\section{UNITED STATES}

Thomas Albert, Senior Scientist, North Slope Borough, Barrow, Alaska

Albert Chapman, OES/OPA, Department of State, Washington, D.C.

Thomas Clingan, Professor of Law, University of Miami, Coral Gables, Florida

Melvin Conant, President, Conant \& Associates, Washington, D.C.

Robert Friedheim, School of International Relations \& Institute for Marine \& Coastal Studies, University of Southern California, Los Angeles, California

Bruce Harlow, Rear Admiral, USN, Assistant Judge Advocate General, United States Navy, Alexandria, Virginia

David Hickok, Director, Arctic Environmental Information \& Data Center, University of Alaska, Anchorage, Alaska

Phillip Jessup, Vice President, William H. Donner Foundation, Inc., New York, New York

James Malone, Assistant Secretary of State for Oceans \& International Environmental \& Scientific Affairs, Department of State, Washington, D.C.

Alfred P. Manning, Rear Admiral, USCG, United States Coast Guard, Washington, D.C.

Walter Parker, Consultant, Anchorage, Alaska

William Westermeyer, Office of Technology Assessment, U.S. Congress, Washington, D.C.

Oran Young, Director, Center for Northem Studies, Wolcott, Vermont

James Zumberge, President, University of Southern California, Los Angeles, California 